\title{
THE POTENTIAL OF ONLINE WRITING TOOLS FOR EFL UNIVERSITY STUDENTS DURING THE COVID-19 PANDEMIC
}

\author{
Fitri Handayani, Nurmadhona Handayani \\ fhandayani1786@gmail.com,nurmadhona@gmail.com \\ Universitas Mahaputra Muhammad Yamin \\ Universitas Putera Batam
}

\begin{abstract}
This study aims to give an overview of potential online writing tools that can be used in teaching writing for EFL university students during the COVID-19 pandemic. This study was a literature review. It explicates online writing tools and reviews previous research exploring the use of these applications for teaching writing. The data was obtained from articles in online academic journals. There were three databases and sites used in finding the articles; Science Direct, Google Scholar, and Research gate. The result shows that there are three potential online writing tools applicable for EFL university students in learning writing from home namely Paragraph Punch, Pro-Writing Aid, and Edmodo. Finally, some suggestions are also offered for lecturers and students regarding the use of online writing tools in teaching writing.
\end{abstract}

Keywords: Online writing tools; EFL university students, COVID-19 Pandemic

\section{INTRODUCTION}

The presence of coronavirus disease (COVID-19) has brought significant changes to human life in the world. The virus, which first appeared in Wuhan, China in December 2019, continued to spread to various parts of the world quickly and became the highest cause of death rates in several countries. As a result, on March 11,
2020, the World Health Organization (WHO) declared COVID-19 as a public health emergency of international concerns in this case a world pandemic. To break the chain of the spread of this virus across Asia, Europe, the Middle East, and the United States, various policies and decisive actions have carried out by countries such as deciding lockdowns, social distancing, and physical distancing. These policies 
bring significant changes to the activities for human life in various aspects such as economy, religion, tourism, and education.

In education, the outbreak of this virus has changed education dramatically. It brings students face 'home-schooling' situations, especially in some of the most heavily affected countries, like China, South Korea, Italy, and Iran (Tam \& El-Azar; 2020). Through this situation, it introduces the students to the rise of online learning and the teaching is undertaking remotely on digital platforms. In Peking University, for example, there are 2,613 undergraduate online courses and 1,824 graduate online courses launch to ensure the normal teaching operation, with 44,700 students stay at homes or dorms (Lei, 2020). Similarly, in Georgia, the Education Management Information System has created the accounts for 55000 teachers and 530100 students and has built-in the virtual classrooms for all classes and relevant subjects by default (Basilaia \& Kvavadze, 2020). This forced digital transformation is the safest way to break the spread of epidemics due to the coronavirus. Therefore, the right of students to get education remains a priority without ignoring mental health and safety.

In Indonesia, The Education system transformed after the announcement an emergency situation over COVID-19. The outbreak of COVID-19 has made several regions closed schools. In Jakarta, for instance, Governor Anies Baswedan announced to close all schools as an effort to decline the spread of COVID-19 on March 16 (Silkina Ahluwalia, 2020). This policy continues followed by other cities and provinces, such as Depok which closed all schools and changed the mode of learning activities with home learning activities from March 16 to March 28 (Jakarta Globe, 2020). The school closure continued to West Java province, Banten province, Central Java province, and other provinces/cities in Indonesia whose are positively affected by COVID 19. This situation made students have experience with online learning.

Besides, the Minister of Education and Culture of the Republic of Indonesia declared a circular letter No. 4 of 2020 Regarding the Implementation of Emergency Education Policy in the Spread of coronavirus Disease (Covid-19) which was established on March 24, 2020. Referring to this letter, the teaching and learning activities are conducted online by considering several points ; (1) online learning must provide meaningful learning experiences, without being burdened with the demands of completing all curriculum achievements for grade promotion and graduation, (2) learning focuses on life skills education, (3) learning activities and assignments can vary between students, according to their interests and conditions, including considering the gap of access/learning facilities at home, (4) evidence or product learning activities from home give quality feedback without being required to give quantitative scores. 
The decision of online learning also faced by university students. Several campuses such as Padang State University, Andalas University, The University of Indonesia have switched their class activities into online learning. They also apply certain academics activities online including mid-semester exams, semester final examinations, practicum, and final duty guidance, theses, and dissertations (Wajdi, Kuswandi, Al Faruq, Zulhijra, Khairudin, Khoiriyah, 2020). The interaction between lecturers and students for online learning varies into certain platforms such as video conferencing tools (zoom and google meet), online social media (WhatsApp), and online learning software (google classroom).

For EFL language learners, facing this online learning during their course also left them with a challenge. In the writing course, for example, writing is a complex skill that cannot learn independently. Mostly, the students need a comprehensive understanding of theories of writing and practical guidance from the lecturer during their writing practice. They need direction, feedback, and even improvement during their writing process. Long-distance learning from home is not optimal in helping them to increase their writing skills. It occurs because of the limited time during virtual learning with lecturers, inaccuracies in the presentation of material, and limited feedback on students' writing. Meanwhile, online learning also made students felt less connected with their peers and lecturers, less aided by their lecturer, dishearten from the technological expectations of online study (Zhang and Perris, 2004; Holley and Oliver, 2010; Otter et al. 2013). For this reason, it needs an appropriate online writing tool platform to bridge online learning activity between students and lecturers in teaching writing, so the students can get comprehensive input and practice in online writing courses.

This article aims to provide information regarding online writing tools that can be used by students while studying online from home. It begins with portrayed online writing tools and reviews some articles investigating the use of online writing tools for writing. Finally, the conclusions and suggestions are offered for students and lecturers in using online writing tools in teaching writing.

\section{REVIEW OF RELATED LITERATURE}

Current technological advances have made many contributions in various fields of life, including in English language teaching and learning. For teaching writing especially, there are various applications, software, websites that are widely available and can be accessed well by teachers and students. As said by Al-Jarf (2007) latest educational technology developments such as word processes, computer programs, e-mail, computer networks, the Internet, and online journal writing have been promoted to develop students' writing abilities. The lecturer can lead students to learn to 
write by combining verbal and visual learning by using these platforms.

Online writing tool is one of the most popular forms which offer possibilities for students' development of academic writing skills (Andreasen, Winters, Hanghøj, \& Larsen, 2014). From this tool, it can monitor students' progress by outlining online assessment and giving feedback, so the students may know their weaker areas. In addition, it also offers innovative ways to streamline the collaborative writing activities between the students in unlimited time.

Several studies have emerged from various kinds of online writing tools applicable for teaching writing based on certain purposes. The tools can be used for checking and correcting students' spelling and grammar, providing students' guidance step by step in the writing process, helping students brainstorming before writing, and facilitating students in having collaborative writing projects. Studies showed that the online writing tool was beneficial to increase students' writing quality. As stated by Miftah \& Raya (2018) which investigated the utilization of Edmodo as an online tool in Indonesian EFL writing class. The result showed that Edmodo as an online tool significantly enhanced the students' ability in writing argumentative essays. On the other side, Miyazoe, T., \& Anderson, T. (2010) also confirmed that three online writing tools (forum, blog, and wiki) in an EFL context contributed a positive effect on students' language learning progress.

\section{RESEARCH METHOD}

This research was a literature review. It is a comprehensive overview of previous research regarding a specific topic by explaining all the findings from the topic to show an indepth understanding of the topic at hand (Denney \& Richard, 2012). This study aims to explore information related to online writing tools EFL university students can use that while studying from home.

In this study, I obtained data collection from articles found in online academic journals. There are three databases and sites used in finding the articles; Science Direct, Google Scholar, and Research gate. Researchers searched for articles using the keywords "Online writing tool" and "online learning" to be entered into databases and sites.

In selecting the articles, the researcher considered the following criteria: 1) the article must be related to using technology in teaching writing for EFL students, 2) the article used was the latest article published in the last 10 years in an academic journal; and dominated by journal articles, 3) the selection process included reviewing the inclusion for titles and abstracts. After the process was completed, I obtained 8 relevant articles to be reviewed specifically as potential online writing tools for EFL students during the COVID -19 pandemic. 


\section{FINDINGS AND DISCUSSION}

There are a lot of substantial variations of online teaching tools available to be accessed by students. All of them have specific features and purposes in gaining students' writing ability. In this article, I would like to provide three possible online writing tools to be accessed easily by EFL university students during learning from home.

\section{Paragraph Punch}

Paragraph Punch is one of the potential online writing tools students can use that while learning to write from home independently. This tool is useful because, during the writing process, students are given in-depth support to organize their thoughts and learn to communicate their ideas in writing. Paragraph Punch is an interactive online site that guides students to build up their paragraph writing skills (Yunus, Salehi, \& Nordin, 2012). This site provides students writing steps starting the process from pre-writing, writing, organizing, editing, rewriting, and publishing. Students can access this site free and use it as a platform for their paragraph writing practice by choosing the demo version.

To get practice in paragraph writing, this site offers 15 writing topics and 1,548 help prompts to lead students through each step in the writing process (Merit Online). In the program, the students can also learn a distinct way to write a paragraph: through reasons, details, sequences, examples, and causes and effects. The display of the site can be seen below.

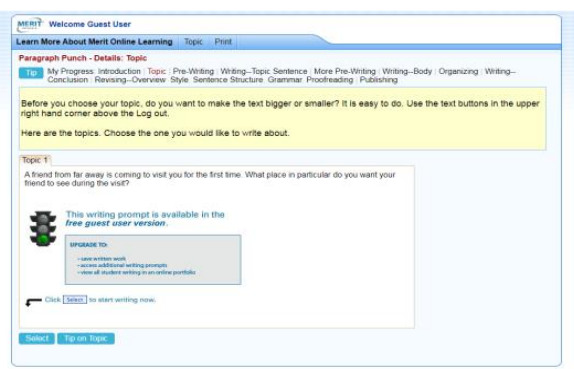

Figure 1. Paragraph Punch display

Paragraph Punch facilitates students learn how to make a paragraph effectively in an organized way. First, writing on this site begins with prewriting. The students might choose a topic for their paragraphs. It encourages them to put in words/phrases appropriate with the topic. During this step, it gives the students prompt questions in helping them to brainstorm the idea. This activity similarly done by the students in the traditional class which mostly collaborate with the lecturer to brainstorm ideas, however, the students collaborate with the writing software on this site. After that, the program shows how to write a topic sentence by display a sample topic sentence. Later, the students are demand to write their topic sentences as an introduction to the paragraph.

After writing a topic sentence, the students are encouraged to make sentences form words / phrases they had before. This activity continues until students can create a few sentences. Furthermore, students are asked to organize the sentences into a complete paragraph. Students are given the choice to erase sentences they think are unnecessary. Also, Paragraph Punch 
offers transition words to make their paragraphs more cohesive.

In writing concluding sentence, the program leads the students by giving a sample first. After that, the students are asked to make their own concluding sentence. After this is done, the draft of students' complete paragraph is displayed to be reviewed by students. They may review by using an option such as 'Add', 'Edit', 'Remove', and 'Move' on the screen. Also, the students can edit the paragraph by using 'spell-checker'. After all the process is done, the students can pubish their paragraph either by saving or printing it.

Several studies have emerged Paragraph Punch is a benefit for students' writing improvement. Lin (2009) emphasized that Paragraph Punch helps check spelling and guide the writing process. Meanwhile, Yunus, Salehi, \& Nordin (2012) which researched ESL Pre-service Teachers' Perceptions on the Use of Paragraph Punch in Teaching Writing found that Paragraph Punch is as an effective program for teaching writing, mostly for beginner level. From its feature, Paragraph Punch enables beginner writers to get a basic understanding of the development of a paragraph by following a step-by-step writing process.

\section{ProWritingAid}

ProWritingAid is a new webbased program to test a text (Ariyanto, Mukminatien, \& Tresnadewi, 2019). This program can be accessed freely through ProWritingAid.com. Particularly, this program aims to facilitate the self-editing writing process by providing aid assesses SPAG (Spelling, Punctuation, and Grammar). In doing its work, this program integrates Microsoft Word, Google Docs, Scrivener, or Google Chrome. By running this program, the students may test their skill independently by having the report and score of their writing. The example of using this tool can be seen in below.

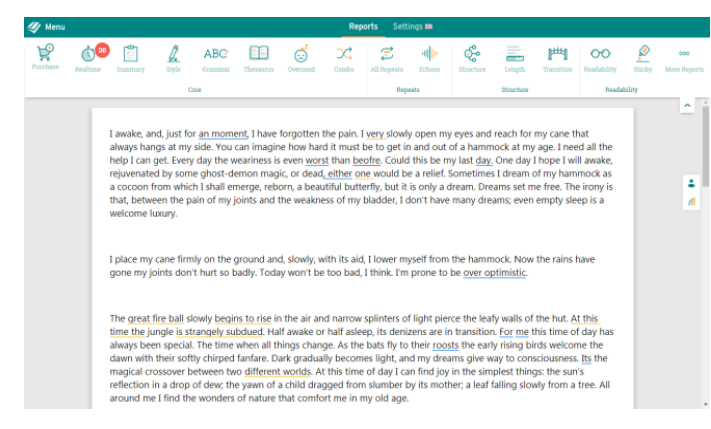

Figure 2. ProWritingAid example.

ProWritingAid is one of the appropriate tools used by the students during learning from home. This program enables students to edit and test their writing without the need to expect from their lecture to assess their work. They can check their speckling, grammar, and punctuation directly and identify errors/mistakes from their writing. The students are also given correction and explanation from their errors. The corrective feedback is a response to a student's linguistic error which comprises the sign of an error, its correct form, and its metalinguistic information about the error (Ellis, Loewen, \& Erlam, 2006). As a result, it can enhance the quality of their writing by facilitating to assess their work independently. In line with this, 
(Ariyanto, Mukminatien, \& Tresnadewi, 2019) emphasized that implementing ProWritingAid and teacher feedback in class was perceived positively by both teacher and students into several reasons: (1) it helped teachers to compensate for the lack of time and explanation in the feedback related to the linguistic accuracy, (2) It also assisted the teacher in providing feedback and allowing the teacher to devote more time to the content and organization of the students' paragraphs, (3) it assists the students as it can give the best of both worlds to help the students detect, learn, and fix their errors from the program and to help the students revise the content and organization of their descriptive paragraph through teacher feedback.

Edmodo

Nic Borg and Jeff O'Hara firstly introduced Edmodo in 2008 with the need to grow the classroom atmosphere to meet the connectedness of the $21 \mathrm{st}$ century world (Alsmari, 2019). It is one of the innovative writing tools beneficial for both teachers and students to get in touch together in an online class. Edmodo provides a private, free, and secure micro-blogging service for online language teaching in which only educators can manage accounts, and only students registered in the group can join and access (Haygood and School, 2012; Majid, 2011).

During the limited interaction between students and lecturers and between the students themselves because of this pandemic, Edmodo appears as the appropriate medium to facilitate it. For lecturers, they can use
Edmodo as a medium to give tasks and quizzes, providing feedback and grades from students' work, storing and sharing writing content material in files and links. For students, Edmodo provides a space for having cooperation and interaction among them. They can easily have contact with each other in sharing information, exchanging ideas, utilizing writing as the medium of communication. The display of the Edmodo site can be seen below.

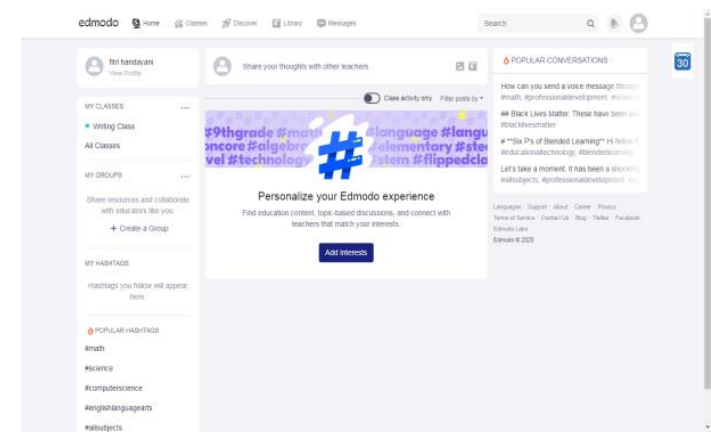

Figure 3. Edmodo display.

In running the program, Edmodo is equipped with features that are very useful for students and teachers in learning writing. The first feature is the assignment. Assignments aim to provide students a platform for accomplish task online. This feature has a time limit and can add files, so students can forward assignments in the form of files directly to their teacher. If students have completed the assignment, then they must click the turn in button. Scores got by students will be automatically saved in the grade book feature. The second feature is the grade book. This feature serves as a record of the grades got by students. Giving this value can be done automatically or manually. The next feature is Polling. Polling can only be 
used by teachers. This feature is useful for knowing how students react to certain things. This feature is a very efficient way to get instant feedback about events that just happened, for example tasks, quizzes, etc. The fourth feature is the Quiz. The quiz works to provide several kinds of evaluations online, both in the form of multiple choices, true/false, and many more. The fifth feature is the Library. The library is a feature used by teachers or lecturers to provide teaching materials in the form of material, videos, pictures, and so on. The existence of this feature is intended so that students can learn the material from the questions given, so they can work on the quiz or the task to the maximum. The sixth feature is File and Link. This feature is used to send notes in the form of attachments such as files and links. The last feature is Parents Codes. This feature serves to provide a chance for parents to monitor all learning activities and achievements of their children.

With the complete features provided in this platform make Edmodo potential to be used as an online student for EFL university students during learning from home. Besides, several studies have revealed the positive impacts of using Edmodo as a writing tool. From the studies, it resulted that Edmodo is potential because of several reasons; (1) it boosted students' confidence and critical thinking, (2) it provides a friendly and safe environment to get interaction and feedback among students on their paragraph, (3) it provides flexible tie to access materials when they could not attend the class, (4) it demonstrates an ideal tool for exchanging thoughts, raising comments and feedback from others, and establishing high writing quality (Duwila \& Khusaini, 2019; Wibowo, 2019; Alsmari, 2019)

\section{CONCLUSION AND SUGGESTION}

With the limited interaction and direct communication related to the learning process between lecturers and students because of the current pandemic situation, supporting media is needed that can facilitate the online learning process well. Online writing tools are one of the alternative solutions used to improve students' writing skills. Paragraph Punch, ProWritingAid, and Edmodo are the potential writing tools to be used by EFL university students. Such tools are helpful to assist both lecturers and students in the writing process and lead writing activities more effectively and efficiently.

Therefore, it is suggested for the EFL university lecturers to draw their attention to the importance of online writing tools as a device to build up students' writing abilities and apply these tools in their class. Meanwhile, it is suggested also for students to become aware and familiar with these tools so they can effectively use it to gain their knowledge in writing.

\section{REFERENCES}

Al-Jarf, R. S. (2007). Online instruction and creative writing by Saudi EFL freshman students. Asian EFL Journal, 22. 
Alsmari, N. A. (2019). Fostering EFL Students' Paragraph Writing Using Edmodo. English Language Teaching, 12(10), 44-54.

Andreasen, L. B., Winther, F., Hanghøj, T., \& Larsen, B. (2014, October). COLWRIT- Collaborative Online Writing in Google Docs: Presenting a Research Design. In European Conference on eLearning (p. 692). Academic Conferences International Limited.

Ariyanto, M. S. A., Mukminatien, N., \& Tresnadewi, S. (2019). Students' and Teacher's Perceptions towards the Implementation of ProWritingAid and Teacher Feedback. Jurnal Pendidikan: Teori, Penelitian, dan Pengembangan, 4(10), 13531363.

Basilaia, G., \& Kvavadze, D. (2020). Transition to online education in schools during a SARS-CoV-2 coronavirus (COVID-19) pandemic in Georgia. Pedagogical Research, 5(4), 1-9.

Denney, A. S., \& Tewksbury, R. (2013). How to write a literature review. Journal of criminal justice education, 24(2), 218-234.

Duwila, S. A., \& Khusaini, T. (2019). Pedagogical Strategy of Writing Paragraph Using Edmodo to Enhance Writing Skill for EFL Students. Journal of English Language Teaching and Islamic
Integration (JELTII), 2(02), 155167.

Ellis, R., Loewen, S., \& Erlam, R. (2006). Implicit and explicit corrective feedback and the acquisition of L2 grammar. Studies in second language acquisition, 28(2), 339368.

Haygood, A. E., \& Schools, C. H. C. C. (2012, March). Blended learning: Using web $2.0 \mathrm{~S}$ to enhance classroom instruction. In 2nd Faculty Development Conference: Teaching and Learning in the 21 st Century (p. 53).

Holley, D., \& Oliver, M. (2010). Student engagement and blended learning: Portraits of risk. Computers \& Education, 54(3), 693-700.

Jakarta Globe. (2020, March 15). Cities urn to Online Learning to Prevent Covid-19 Spreading Among Students. Jakarta Globe. https://jakartaglobe.id/news/citiesturn-to-online-learning-toprevent-covid19-spreadingamong-students/

Lei, G. (2020). Peking University spring semester begins with online teaching. Peking University News. Retrieved from http://news.pku.edu.cn/xwzh/979e 47acd7bf4c9592945323a2292f4d. ht

Lin, S. M. (2009). HOW COMPUTERMEDIATED OMMUNICATION AFFECTS 
STUDENTS'WRITING

ROCESSES AND WRITING PERFORMANCE.

Majid, A. N. (2011). The use of information technology in teaching English: An attempt to develop student-centered learning at

Telkom

Polytechnic. Konferensi Nasional ICT-M Politeknik Telkom.

Miftah, M. Z., \& Raya, I. P. (2018). Utilization of Edmodo as an online tool in EFL writing class to increase students' writing ability. Register Journal,11(1), 37-58.

Miyazoe, T., \& Anderson, T. (2010). Learning outcomes and students' perceptions of online writing: Simultaneous implementation of a forum, blog, and wiki in an EFL blended learning setting. System, 38(2), 185-199.

Otter, R. R., Seipel, S., Graeff, T., Alexander, B., Boraiko, C., Gray, J., .. \& Sadler, K. (2013). Comparing student and faculty perceptions of online and traditional courses. The Internet and Higher Education, 19, 27-35.

Silkina, A. (2020, April 5). 2020 Elearning is on the rise in Indonesia amid COVID-19 pandemic. CGTN.

https://news.cgtn.com/news/202004-05/E-learning-is-on-the-risein-Indonesia-amid-COVID-19- pandemic-

Pr5Bp1HXoI/index.html

Tam, G., Diana E. (2020, March 15). Three ways the coronavirus pandemic could reshape education. The Mandarin. https://www.themandarin.com.au/ 127368-three-ways-thecoronavirus-pandemic-couldreshape-education/

Wajdi, M. B. N., Kuswandi, I., Al Faruq, U., Zulhijra, Z., Khairudin, K., \& Khoiriyah, K. (2020). Education Policy Overcome Coronavirus, A Study of Indonesians. EDUTEC: Journal of Education And Technology, 3(2), 96-106.

Wibowo, S. E. (2019). EDMODO: IMPROVING STUDENTS'WRITING KILL. Lentera: Jurnal Ilmiah Kependidikan, 12(2), 231-236.

Yunus, M. M., Salehi, H., \& Nordin, N. (2012). ESL pre-service teachers' perceptions on the use of paragraph punch in teaching writing. English Language Teaching, 5(10), 138.

Zhang, W. Y., \& Perris, K. (2004). Researching the efficacy of online learning: A collaborative effort amongst scholars in Asian open universities. Open Learning: The Journal of Open, Distance and eLearning, 19(3), 247-264 